\title{
Neuroprotective Potential of Pituitary Adenylate Cyclase Activating Polypeptide in Retinal Degenerations of Metabolic Origin
}

\author{
Robert Gábriel1,2*, Etelka Pöstyéni and Viktória Dénes ${ }^{1}$ \\ ${ }^{1}$ Department of Experimental Zoology and Neurobiology, University of Pécs, Pécs, Hungary, ${ }^{2}$ János Szentágothai Research \\ Centre, University of Pécs, Pécs, Hungary
}

OPEN ACCESS

Edited by:

Giovanni Casini,

University of Pisa, Italy

Reviewed by:

Claudio Bucolo,

University of Catania, Italy

Ilaria Piano,

University of Pisa, Italy

Hirokazu Ohtaki,

Showa University, Japan

*Correspondence:

Robert Gábriel

gabriel@gamma.ttk.pte.hu

Specialty section:

This article was submitted to

Neurodegeneration,

a section of the journal

Frontiers in Neuroscience

Received: 26 June 2019

Accepted: 12 September 2019

Published: 09 October 2019

Citation:

Gábriel R, Pöstyéni E and Dénes V (2019) Neuroprotective Potential of Pituitary Adenylate Cyclase Activating Polypeptide

in Retinal Degenerations of Metabolic

Origin. Front. Neurosci. 13:1031.

doi: 10.3389/fnins.2019.01031
Pituitary adenylate cyclase-activating polypeptide (PACAP1-38) is a highly conserved member of the secretin/glucagon/VIP family. The repressive effect of PACAP1-38 on the apoptotic machinery has been an area of active research conferring a significant neuroprotective potential onto this peptide. A remarkable number of studies suggest its importance in the etiology of neurodegenerative disorders, particularly in relation to retinal metabolic disorders. In our review, we provide short descriptions of various pathological conditions (diabetic retinopathy, excitotoxic retinal injury and ischemic retinal lesion) in which the remedial effect of PACAP has been well demonstrated in various animal models. Of all the pathological conditions, diabetic retinopathy seems to be the most intriguing as it develops in $75 \%$ of patients with type 1 and $50 \%$ of patients with type 2 diabetes, with concomitant progression to legal blindness in about 5\%. Several animal models have been developed in recent years to study retinal degenerations and out of these glaucoma and age-related retina degeneration models bear human recapitulations. PACAP neuroprotection is thought to operate through enhanced CAMP production upon binding to PAC1R. However, the underlying signaling network that leads to neuroprotection is not fully understood. We observed that (i) PACAP is not equally efficient in the above conditions; (ii) in some cases more than one signaling pathways are activated; (iii) the coupling of PAC1-R and signaling is stage dependent; and (iv) PAC1-R is not the only receptor that must be considered to interpret the effects in our experiments. These observations point to a complex signaling mechanism, that involves alternative routes besides the classical cAMP/protein kinase A pathway to evoke the outstanding neuroprotective action. Consequently, the possible contribution of the other two main receptors (VPAC1-R and VPAC2-R) will also be discussed. Finally, the potential 
medical use of PACAP in some retinal and ocular disorders will also be reviewed. By taking advantage of, low-cost synthesis technologies today, PACAP may serve as an alternative to the expensive treatment modelities currently available in ocular or retinal conditions.

Keywords: PACAP, signaling, retina degeneration, metabolic origin, neuroprotection

\section{INTRODUCTION}

Neuropeptides have a fundamental role in the maturation of the nervous system and their functional consequences appear in countless biological mechanisms, both in physiological and in pathological conditions. Peptides may act as neurotransmitters, neuromodulators or neurohormones, therefore their function in neuronal development/regeneration may confer crucial protective roles during pathological conditions (Strand, 2003; Casini, 2005; Cervia and Casini, 2013).

Pituitary adenylate cyclase-activating polypeptide (PACAP) was first isolated from ovine hypothalamic extract as a 38 amino acid long peptide (PACAP1-38) in 1989 (Miyata et al., 1989). It belongs to the vasoactive intestinal peptide (VIP)/secretin/glucagon peptide family members and has another isoform eleven amino acids shorter (PACAP1-27) which is less dominant in vertebrates (Arimura and Shioda, 1995; Vaudry et al., 2009). Unless stated otherwise, we refer PACAP1-38 as PACAP throughout this paper.

The biological effects of PACAP are mediated by three types of G-protein coupled receptors which have seven transmembrane domains (PAC1-R, VPAC1-R, VPAC2-R, see below). PACAP binds to pituitary adenylate cyclase-activating polypeptide type I receptor (PAC1-R) with approximately $100 \mathrm{x}$ higher affinity than VIP while both peptides have similar affinities for VPAC1$\mathrm{R}$ and VPAC2-R. These receptors are widely distributed in the central and peripheral nervous system (Vaudry et al., 2000; Laburthe et al., 2007). The variable effects of PACAP are due

\footnotetext{
Abbreviations: AC, adenylate cyclase; Akt, protein kinase B; ATP, adenosine triphosphate; BCCAO, bilateral carotid artery occlusion; Bcl-2, B-cell lymphoma 2 protein; BDNF, brain-derived neurotrophic factor; cAMP, cyclic adenosine $3^{\prime}, 5^{\prime}$-monophosphate; CNS, central nervous system; CNTF, ciliary neurotrophic factor; CRE, cAMP response element; CREB, cAMP response element-binding protein; DAG, diacylglycerol; DR, diabetic retinopathy; ERK 1/2, extracellular signal-regulated-kinase $1 / 2 ; \mathrm{G} \alpha / \beta / \gamma, \mathrm{G}$ protein alpha/beta/gamma subunit; GCL, ganglion cell layer; GFAP, glial fibrillary acidic protein; GSK, glycogen syntase kinase-3; HIF $1 \alpha$, hypoxia-inducible factor $1 \alpha$; HRE, hypoxia response element; IL6, interleukin6; INL, inner nuclear layer; IP3, inositol trisphosphate; IPL, inner plexiform layer; JNK, jun N-terminal protein kinase; LPS, lipopolysaccharide; MAPK, mitogen activated protein kinase; MAPK, mitogen-activated protein kinase; MGS, monosodium glutamate; mRNA, messenger RNA; NaAsO2, sodium arsenite; NFкB, nuclear factor $\kappa \mathrm{B}$; NR2B, $N$-methyl D-aspartate receptor subtype 2B; OCTR, ocreotide; ONL, outer nuclear layer; OPL, outer plexiform layer; PAC1-R, pituitary adenylate cyclase-activating polypeptide type I receptor; PACAP, pituitary adenylate cyclase-activating polypeptide; PARP, poly ADP ribose polymerase; phospho-CaMKII, calcium/calmodulin-dependent protein kinase II; PI3K, phoshoinositide 3-kinase; PIP2, phosphatidylinositol 4,5-bisphosphate; PKA, protein kinase A; PKC $\alpha$, protein kinase $\mathrm{C}$ alpha; PKC, protein kinase $\mathrm{C}$; PLC, phospholipase C; PLC, phospholipase C; ROS, reactive oxygen species; RPE, retinal pigment epithelium; SST, somatostatin; STZ, streptozotocin; TNF $\alpha$, tumor necrosis factor alpha; VEGF, vascular endothelial growth factor; VEGF-R, VEGF- receptor; VIP, mitogen activated protein kinase; VPAC1-R, vasoactive intestinal polypeptide receptor 1; VPAC2-R, vasoactive intestinal polypeptide receptor 2 .
}

to the activation of diverse signal transduction pathways and their outcomes depend on which receptor types have been activated. AC, PLC and $\mathrm{Ca}^{2+}$ are main effectors during the signal transduction mechanisms of PACAP (Spengler et al., 1993; Pisegna and Wank, 1996). PAC1R and VPAC1R are coupled to AC, which leads to cyclic adenosine $3^{\prime}, 5^{\prime}$-monophosphate (cAMP) level elevations and the subsequent activation of PKA, which in turn could activate the MAPK pathway. Both receptor types are coupled to PLC as well, which leads to the stimulation of $\mathrm{Ca}^{2+}$ mobilization and the activation of the protein kinase C (PKC) pathway. VPAC2R subtype also seems to activate the AC signaling pathway. Beyond the receptor types, activation of different pathways depends on the ligands, the tissue type, and the stage of the development (Filipsson et al., 1998; Basille et al., 2000; Vaudry et al., 2000).

PACAP and its receptors are present in the CNS and in peripheral organs of mammals (Arimura and Shioda, 1995; Vaudry et al., 2009). In the CNS it behaves as a neurotransmitter or neurotrophic factor and is expressed in the hippocampus, cerebellum, hypothalamus and in several brainstem nuclei (Hannibal, 2002; Lee and Seo, 2014). Several studies discussed its neuroprotective effects in neurodegenerative diseases such as in stroke, brain ischemic injuries, Alzheimer's diseases and in Parkinsonism (Wang et al., 2008; Atlasz et al., 2010; Han et al., 2014; Matsumoto et al., 2016). Studies have revealed the expression of PAC1-R in the conjunctiva while PACAP/PAC1$\mathrm{R}$ show higher expression in the lacrimal glands, in the cornea and in the retina (Wang et al., 1995; Elsas et al., 1996). In the retina, the nerve cell bodies in the GCL, some amacrine cells and horizontal cells show PACAP immunopositivity (Izumi et al., 2000; Denes et al., 2014). PAC1-R is strongly expressed in the GCL, in the INL and shows lower expression in the outer and inner plexiform layers (OPL, IPL) as well as in the ONL (Seki et al., 1997). To date, several studies have described the significant neuroprotective potential and neurotrophic effects of PACAP in relation to retinal metabolic disorders. Although its physiological action is incompletely elucidated, this peptide exerts neuroprotective and trophic actions by regulating cell survival and death, not only during the development and maturation of the nervous system but also in pathological conditions. Although pivotal roles in retinal metabolic disorders have been extensively investigated, the mechanisms are still not well understood and further signal transduction pathways may await to be revealed.

The primary aims of the present review are to summarize our knowledge about PACAP action in the retina in various physiological and pathological conditions (diabetic retinopathy, excitotoxic retinal injury and ischemic retinal lesion) and to discuss the potential signal transduction pathways in the context 
of its protective action. Particularly, we pay special attention to (i) the lack of PACAP in the retina and supplementation of PACAP during early postnatal development; (ii) PAC1-R subtypes in the retina and their possible involvement in the neuroprotective events; and (iii) role of PACAP in mobilizing the immune system, both white blood cells and chemical messengers, to achieve retinal neuroprotection. Finally, we summarize the synergistic and diverging pathways through which PACAP acts and achieves functional improvement in concerted action with other neuropeptides.

\section{PACAP CONTRA RETINAL DEGENERATION WITH METABOLIC ORIGINS}

As we mentioned above, the physiological role of PACAP in the adult retina is not well established. Clearly, an emerging theory is that the lack of endogenous PACAP would accelerate age-related degeneration (Reglodi et al., 2018). PACAP deficiency mimics aspects of age-related pathophysiological changes including increased neuronal vulnerability and systemic degeneration accompanied by increased apoptosis, oxidative stress, and inflammation thus mimicking early aging. In support of this theory, it has been proven recently that endogenous PACAP has a protective effect during retinal inflammation. Experiments with PACAP KO mice revealed that intraperitoneal injection of LPS induced markedly more seriously eye-inflammation in PACAP KO mice than in the wild type group. During the process of inflammation, protein kinase $B$ (pAkt) and glycogen synthase kinase-3 (pGSK) levels decreased in PACAP KO mice while cytokines (sICAM-1, JE, TIMP-1) were elevated (Vaczy et al., 2018).

\section{INVOLVEMENT OF PACAP IN RETINAL CELL DEVELOPMENT AND AGING}

In the CNS numerous extrinsic and intrinsic factors contribute to the formation of mature tissue by the precise regulation of the appropriate number and distribution of neurons. Neuropeptides influence many developmental processes of the CNS in a regulated way (Casini, 2005). In the developing retina, progenitor cells proliferate and differentiate into various retinal cell types as a result of numerous regulated cell cycle processes and develop into the final multi-layered structure of the retina. In postnatal (P6, P9) rat retinas PACAP treatment modulates cell death by activation of cAMP-PKA pathways (Silveira et al., 2002). Njaine et al. (2010) have investigated the exact timing and role of PACAP and its receptors in the cell generation of the developing rat retina. PAC1-R is expressed as early as E16 during development while VPAC1-R and VPAC2-R are expressed later, but then are present at all other stages. PACAP treatment resulted in an anti-proliferative effect by phosphorylation of CREB in cyclin D1 expressing retinal progenitor cells after PACAP receptor activation. Conversely, PACAP receptor activation led to a decreased level of cyclin D1 mRNA and further decreased by a combined treatment with PACAP and the cAMP degradation inhibitor IBMX. These findings have shown that PACAP has control over a subpopulation of progenitor cells and modulate cell proliferation in the developing retinal tissues (Njaine et al., 2010). Interestingly, PACAP shows both pro- and anti-apoptotic effects on postnatal retinal development in rat models. Caspase activity analysis has shown dose- and stage-dependent effects of PACAP on developmental apoptosis in rat retinas. Intravitreal injection of PACAP from postnatal day 1 (P1) to P7 induces apoptosis during the early stage of the retinogenesis. When 100 pmol PACAP was injected, it increased caspase 3/7 activity at P1, P3, and P5, but had no effect at P7. At P3, treatment repressed caspase $3 / 7$ activity $18 \mathrm{~h}$ after the intravitreal injection, however, their levels increased $24 \mathrm{~h}$ post-injection. Apparently, PACAP treatment did not exert anti-apoptotic effects at P1, P5, and P7 rat retinas (Nyisztor et al., 2018). These findings warn us to re-evaluate PACAP action cautiously, always taking the timing and concentrations into account, especially in development. Unfortunately, not much is known about the functions of this peptide in mature retinas. Aging experienced as loss of function is accompanied by functional and morphological changes in retinal tissues (Gao and Hollyfield, 1992; Curcio and Drucker, 1993; Ramirez et al., 2001; Kovacs-Valasek et al., 2017). PACAP KO mice show accelerated age-related changes compared to wild type retinas. Altered structural changes included enhanced loss of ganglion cells and spouting of rod bipolar cell dendrites into the ONL in aging PACAP KO mice. Protein kinase C (PKC) $\alpha$ level in rod bipolar cells has been reduced in this condition. In contrast, GFAP levels have increased with an absence of endogenous PACAP. At the same time, PAC1-R has been upregulated in PACAP deficient young adult mice retinas. Surprisingly, the authors did not find differences in the histological structure of young adult PACAP KO and wild type mice (Kovacs-Valasek et al., 2017). These results suggest that PACAP contributes to maintaining the biochemical balance within neurons and glial cells. Thus, in the absence of this peptide, aging processes (e.g., reactive oxygen species formation) may gain strength earlier than in animals with normal PACAP levels.

\section{PACAP RECEPTOR TYPES EXPRESSED IN RETINA}

In the retina, the presence of four PAC1-R isoforms has been verified during postnatal development. The Null isoform showed no impressive changes at early stages (P1 to P5), but then manifested a decline from P5 to P15. Null message levels fell almost to zero in early adult ages. The Hip isoform had a similar expression pattern. The Hiphop1 isoform showed one prominent peak at P10. The Hop1 splice variant did not change much between P1 and P5, but thereafter it showed a significant increase at P10, P15, and P20. This seems to be the major isoform during adult life. Depending on the type of the PAC1-R isoform, PACAP can induce precursor cells to exit the cell cycle (through activation of the Null isoform ( $\mathrm{Lu}$ and DiCicco-Bloom, 1997) or can promote proliferation in neuroblasts (if they express the Hop isoform (Lu et al., 1998). Interestingly, expression of both 
Hip and Hop1 isoforms displays a sudden increase at P10 prior to eye opening. Due to technical difficulties, PAC1-R bearing retinal cells could not be sorted by their respective isoforms (isoform-specific antibodies are not available currently).

Based on these experimental results, a subsequent study has investigated the exact time period of isoform shift from postnatal day 5-10. The transcript level of Hip mRNA decreased from P6 through P9, while Hop1 expression level did not display any changes until P10. Consequently, a Hip/Hop1 isoform shift occurs between P6 and P8, which could alter PACAP functions in the postnatal rat retina (Denes et al., 2014). In contrast to the PAC1-R expression levels of the VPAC1-R receptor did not change during postnatal retinal development, though both the mRNA and protein could be detected in all selected time points. A similar scenario has been found in the case of VPAC2-R. Therefore, these receptors appear to be expressed in the newborn as well as in the adult retina, with similar intensity both at message and protein level (Lakk et al., 2012).

\section{RETINAL PATHOLOGIES AND PACAP}

Retinal diseases fall into two main categories: inherited disorders and problems of metabolic origin. Both conditions have attracted substantial research interest. According to our PubMed survey, approximately 4,000 papers have been published in the last 10 years dealing with the former and about 3,000 with the latter. Approximately half of the papers deal either with diagnostic advances or treatment options. Below we shall summarize some of the experimental results regarding the three most common conditions: diabetic retinopathy, excitotoxic retinal injury and ischemic retinal conditions.

\section{Diabetic Retinopathy and PACAP}

Diabetes is a multifactorial, metabolic disorder which appears to be the result of several pathological metabolic processes with increased morbidity statistics worldwide. In 2017, 425 million adults lived with diabetes and the size of the affected population will rise to 629 million until 2045 (International Diabetes Federation, 2017) ${ }^{1}$. DR is a microvascular complication of diabetes and the leading cause of vision loss (Cheung et al., 2010; Antonetti et al., 2012). DR is also considered as a chronic inflammatory disorder; low-grade inflammation has been observed in the retinas of both diabetic animals and human patients (Krady et al., 2005; Kern, 2007; Zeng et al., 2008). Patients with 1 type diabetes have a higher risk of DR than with the type 2 disease (Yau et al., 2012). DR has two distinguishable stages depending on the presence of neovascularization: an earlier non-proliferative phase characterized by abnormalities in the microvasculature, which could progress into a proliferative phase with macular neovascularization (Cheung et al., 2010).

The pathogenesis of DR includes increased polyol and hexosamine pathway activation, higher advanced glycation endproducts production and the activation of PKC pathways. These altered signaling mechanisms could result in oxidative

${ }^{1}$ http://www.diabetesatlas.org stress and chronic inflammation. Retinal microglial cells become activated and migrate in the subretinal space in several retinopathies, including DR (Zeng et al., 2000, 2008). The activation of microglia induced by hyperglycemia has been associated with the early development of DR, and occurs as early as electroretinographic modifications (Gaucher et al., 2007; Kern, 2007). Cytokines, released by activated microglia, were shown to contribute to neuronal cell death (Krady et al., 2005). They stimulate the production of cytotoxic substances, such as TNF $\alpha$ and ROS, proteases and even excitatory amino acids, which may induce neuronal degeneration. Leukocytemediated retinal cell apoptosis is among the earliest pathological manifestations of DR and results in the formation of a cellularoccluded capillaries, microaneurysms, and vascular basement membrane thickening (Kern and Engerman, 1995). Macrophages have long been known to play a major role in the pathogenesis of proliferative vitreoretinal disorders. In human DR, all types of macrophages could be detected regardless of clinical history and duration of the disease (Esser et al., 1993). Consequences of vascular occlusions contribute to neurodegeneration and dysfunction of the retina (Frank, 2004; Cheung et al., 2010; Giacco and Brownlee, 2010). Neuroprotective effects of PACAP in this pathological condition are complex because they have both structural, physiological and synaptic aspects as evidenced by many papers in this field (Table 1). In a rat model, intravitreal injection of PACAP ameliorated the structural changes of the retina in streptozotocin-induced DR. This treatment attenuates neuronal cell loss in the GCL, reduces cone cell degeneration and shows normal dopaminergic amacrine cell number compared to untreated diabetic retinas. These findings have demonstrated the significant neuroprotective effect of PACAP and its therapeutic potential in DR (Szabadfi et al., 2012). In their latest study, Maugeri et al. (2019) have provided evidence that PACAP138 protects not only neurons, but also the retinal pigmented epithelium both in vivo and in vitro. In another study, the intraocular PACAP injection attenuated the retinal injury by increasing the anti-apoptotic p-Akt, extracellular signalregulated-kinase (p-ERK1/2), PKC and B-cell lymphoma 2 (Bcl2) proteins levels, meanwhile the pro-apoptotic phosphorylated p38MAPK and activated caspase $-3,-8$, and -12 levels were decreased. As a result PACAP treatment significantly decreased apoptotic cell numbers compared to untreated diabetic rats and attracted a number of unidentified immune cells into the retina through the inner limiting membrane (Szabadfi et al., 2014). At the same time, electron microscopic analysis found altered synaptic structures in the diabetic retinas, in contrast to PACAP-treated diabetic groups, where more bipolar ribbon synapses appeared in the inner plexiform layer indicating higher levels of synapse-retention (Szabadfi et al., 2016). Giunta and his colleagues have described that MAPK transcripts levels were modified in the retina of diabetic rats during the early stages and the levels of PACAP, VIP and their receptors were all significantly downregulated as compared to nondiabetic rats (Giunta et al., 2012). At the same time, PACAP treatment has increased the PAC1-R expression in the retina, sometimes even in cells where PAC1-Rs are normally not present (Szabadfi et al., 2012). 
TABLE 1 | In vivo and in vitro experiments with PACAP application in DR (rat retina).

\begin{tabular}{|c|c|c|c|}
\hline & References & Study aim & Findings \\
\hline \multirow[t]{6}{*}{ In vivo } & $\begin{array}{l}\text { Giunta et al., } \\
2012\end{array}$ & $\begin{array}{l}\text { PACAP, VIP and their receptors expression change in retina } \\
\text { of streptozotocin-induced diabetic rats. }\end{array}$ & $\begin{array}{l}\text { The expression of peptides and their receptors were decreased after } \\
\text { induction of diabetes. PACAP38 intravitreal injection restored diabetic } \\
\text { changes in Bcl-2 and p53 expression to non-diabetic levels. }\end{array}$ \\
\hline & $\begin{array}{l}\text { Szabadfi et al., } \\
2012\end{array}$ & $\begin{array}{l}\text { Highlights the protective effects of PACAP in diabetic } \\
\text { retinopathy }\end{array}$ & $\begin{array}{l}\text { PACAP ameliorated structural changes in DR, attenuated neuronal cell loss } \\
\text { and increased the levels of PAC1-receptor and tyrosine-hydroxylase. }\end{array}$ \\
\hline & $\begin{array}{l}\text { D'Amico et al., } \\
2015\end{array}$ & $\begin{array}{l}\text { The effects of PACAP in hyperglycemic retina is mediated } \\
\text { by modulation of HIFs' expression in retina. }\end{array}$ & $\begin{array}{l}\text { In diabetic rats } \mathrm{HIF}-1 \alpha \text { and HIF-2 } \alpha \text { expression decreased after PACAP } \\
\text { intraocular administration while HIF-3 } \alpha \text { downregulated in retinas of STZ } \\
\text { injected rats and increased after PACAP treatment. }\end{array}$ \\
\hline & $\begin{array}{l}\text { Szabadfi et al., } \\
2016\end{array}$ & $\begin{array}{l}\text { Analyze the synaptic structure and proteins of } \\
\text { PACAP-treated diabetic retinas after intravitreal PACAP } \\
\text { administration. }\end{array}$ & $\begin{array}{l}\text { In the PACAP-treated diabetic retinas more bipolar ribbon synapses were } \\
\text { found intact in the inner plexiform layer than in DR animals. Degeneration of } \\
\text { bipolar and ganglion cells could be ameliorated by PACAP treatment. }\end{array}$ \\
\hline & $\begin{array}{l}\text { D'Amico et al., } \\
2017\end{array}$ & $\begin{array}{l}\text { Protective role of PACAP through IL1 } \beta \text { and VEGF } \\
\text { expression in rat diabetic retinopathy }\end{array}$ & $\begin{array}{l}\text { PACAP reduced the IL-1 } \beta \text { expression and downregulates VEGF, VEGFRs in } \\
\text { STZ-treated animals. }\end{array}$ \\
\hline & $\begin{array}{l}\text { Maugeri et al., } \\
2019\end{array}$ & $\begin{array}{l}\text { Effect of PACAP-38 against high glucose damage is } \\
\text { mediated by EGFR phosphorylation in retina. }\end{array}$ & PACAP-38 induced p-EGFR over-expression in diabetic rats retina. \\
\hline In vitro & $\begin{array}{l}\text { Maugeri et al., } \\
2019\end{array}$ & $\begin{array}{l}\text { Effect of PACAP-38 on ARPE-19 cells exposed to } \\
\text { hyperglycemic/hypoxic insult }\end{array}$ & PACAP-38 treatment improved cell viability. \\
\hline
\end{tabular}

Unfortunately, there is no data available regarding VPAC1-R and VPAC2-R involvement in the PACAP response in the retina. However, VIP and PACAP have been shown to cooperate in functional studies by using other disease models (Schratzberger et al., 1998; Ganea and Delgado, 2003; Abad et al., 2016).

\section{Excitotoxic Retinal Injury and PACAP}

Excitotoxic retinal injury in animal models mimics the changes associated with elevated intraocular pressure in human that causes glaucoma. Several studies have examined the neuroprotective effect of PACAP in excitotoxic retinal injuries. In normal conditions, glutamate is a neurotransmitter molecule in the retina, however, in high concentration it causes excessive stimulation of glutamate receptors and leads to excitotoxicity. In animal models of excitotoxic retinal injury, monosodium-glutamate treatment is used in vivo to model this pathological condition.

Monosodium glutamate (MSG) injection treatment has caused severe degenerations in neonatal rat retinas (Tamas et al., 2004; Atlasz et al., 2009). If prior to MSG treatment PACAP was injected unilaterally into the vitreous body of neonatal rat eyes, the MSG-induced degeneration became less pronounced. PACAP was applied in two different concentrations ( 1 and $100 \mathrm{pmol}$ ) to examine the dose-dependency of PACAP treatment in excitotoxic retinal injury. After MSG treatment the thickness of the entire retina was reduced by more than half and the reduction was especially due to the degeneration of the inner layers. Retinas of rats treated with 100 pmol PACAP showed significantly less damage than the retinas of animals treated with 1 pmol PACAP. These findings have described how PACAP could significantly attenuate the degeneration of the retina and underlined the importance of the dose-dependent effects of PACAP (Tamas et al., 2004). In another study, two different forms of PACAP (PACAP1-27, PACAP1-38) and their antagonists (PACAP6-38, PACAP6-27) have been tested in excitotoxic injury. The thickness of the retina has been significantly reduced, much of the IPL disappeared, the GCL and the INL cells intermingled and the
ONL cells were swollen. During the investigation, PACAP1-38 and PACAP1-27 treated groups have shown retained retinal structure and the INL and GCL remained well separated. The two isoforms of PACAP have shown the same degree of neuroprotection after MSG treatments. The application of two PACAP antagonists after MSG injection did not ameliorate the MSG-induced retinal degenerations and led to a pronounced degeneration in the rat retina (Atlasz et al., 2009). During these experiments, the degenerations of the inner retinal layers were ameliorated by PACAP treatment. Note that PAC1-R distribution in the retina corresponds to the location of the protective effect because it shows the highest expression in the INL and in the GCL, and the lowest in the ONL and OPL (Seki et al., 2000). Another study examined the molecular background of signal transduction pathways underlying the neuroprotective effect of PACAP in MSG-induced retinal injury. The authors found that MSG inhibits the production of the anti-apoptotic molecules (phospho-PKA, phospho-Bad, Bcl-xL and 14-3-3 proteins) using rat models. PACAP treatment attenuates these effects by inducing the activation of the anti-apoptotic pathway by phosphorylation of PKA and Bad molecules and increasing the levels of Bcl-xL, and 14-3-3 proteins (Racz et al., 2007). These results highlighted that PACAP has a retinoprotective effect in glutamate induced injuries by reducing the pro-apoptotic pathways, while inducing anti-apoptotic signaling.

Interestingly, an enriched environment surrounding the experimental animals has also been shown to provide strong protective effect. A combination of enriched environment and PACAP treatment, however, did not further improve the protective effect, suggesting that these two treatments may utilize the same pathway for protection (Kiss et al., 2011).

\section{Retinal Ischemic Conditions and PACAP}

Retinal ischemia, as well as ischemia-reperfusion, causes inflammation which leads to injury progression, though inflammation usually helps in neuronal repair. These conditions contribute to excess ROS production, increase intracellular 
calcium levels and initiate mitochondrial damage. In addition, MAPKs, nuclear factor $\kappa \mathrm{B}(\mathrm{NF} \kappa \mathrm{B})$ and hypoxia-inducible factor $1 \alpha(\mathrm{HIF} 1 \alpha)$ are also activated when ischemic conditions elicit inflammation (Rayner et al., 2006; Wang et al., 2014; Kovacs et al., 2019). In the BCCAO model, PACAP activated one of the most important cytoprotective pathways, the PI3K-Akt, and suppressed the p38 MAPK and JNK pathways (Szabo et al., 2012) just like PARP inhibitors (Mester et al., 2009). Furthermore, a neurotrophic agent with a similar mode of action, CNTF, a member of the IL6 family (Wen et al., 2012), has also been tested in the form of intravitreal injection in preclinical studies. Using 12 animal models from 4 different species, researchers described a strong neuroprotective effect on photoreceptors and ganglion cells in the retina (Tao et al., 2002; Pease et al., 2009; Flachsbarth et al., 2014; Lipinski et al., 2015).

The effect of PACAP fragments has also been tested extensively in this model (Werling et al., 2014). The rationale for this study was that bioavailability and fast degradation of PACAP limit its therapeutic use and therefore scientific attention has been drawn to shorter fragments, especially the ones where C-terminus is truncated (Bourgault et al., 2009; Bourgault et al., 2011; Dejda et al., 2011). Therefore, it was necessary to test whether shorter PACAP fragments $(4-13,4-22,6-10,6-15,11-$ 15, and 20-31) have any effect on retinal lesions caused by chronic retinal hypoperfusion. Since the N-terminal fragments show a high similarity with the structure of VIP, and the 4-13 domain shows high selectivity to the PAC1-R, the prospect of creating a short and effective peptide fragment with a similar neuroprotective potential to PACAP seemed very promising. However, the authors came to the conclusion that the natural form of the peptide, PACAP1-38, is the most effective in retinal ischemia, and the 38 amino acid form of the peptide cannot be replaced by another fragment or another member of the peptide family (Werling et al., 2014). It has also been shown that PACAP mediates functional recovery after 14 days of intraocular treatment (Danyadi et al., 2014), probably through downregulation of VEGF production and glutamate release (D’Alessandro et al., 2014).

\section{COMMON, SYNERGISTIC AND DIVERGING PATHWAYS OF PACAP SIGNALING TO ACHIEVE FUNCTIONAL IMPROVEMENT}

In the next few paragraphs, we aim to summarize the pathways activated, directly or indirectly by PACAP receptors (Figure 1). Unfortunately, most studies do not provide evidence which PACAP receptors are involved in the processes described below. Nevertheless, all the available data point to a critical function of PACAP in neuroprotection.

\section{Downregulation of Vascular Endothelial Growth Factor (VEGF)}

Vascular endothelial growth factor, a dimeric glycoprotein functions as a mitogen by stimulating proliferation and migration of endothelial cells. It is also responsible for formation of new blood vessels (Ferrari and Scagliotti, 1996). The receptors of this signal molecule (VEGF- receptor 1, VEGF-R1 and VEGF- receptor 2, VEGF-R2) have tyrosine kinase domains and contribute to angiogenesis (Yancopoulos et al., 2000; Rahimi, 2006).

Among retinal cell types, mainly astrocytes, Müller glia cells, retinal pigment epithelium (RPE) and pericytes produce VEGF (Chalam et al., 2014). VEGF expression level is increased under low-oxygen concentrations through the induction of hypoxiainducible factor 1 (HIF-1) expression. Hypoxia inducible factors (HIFs, see later) are modulators in hypoxia and cause endothelial cell transmigration across the RPE in the eye. These endothelial cells contribute to new vessel formation under VEGF control (Wang et al., 1995; Kaur et al., 2008; Skeie and Mullins, 2009). Elevated VEGF production leads to angiogenesis in order to supply tissues in hypoxic conditions (Kim et al., 2015). However, the newly generated blood vessels scatter light, and thus, instead of contributing to a better vision, they actually deteriorate visual acuity.

Studies have described diverse effects of PACAP on VEGF expression levels. Both PACAP and VIP are able to modulate HIF and VEGF expression during diabetic macular edema. VEGF expression is increased during hyperglycemic insult compared to control conditions. This effect can be ameliorated by PACAP or VIP treatment which could reduce the expression of VEGF and its receptors (Maugeri et al., 2017). Conversely, in another study, unrelated to diabetes, intravitreal treatment with PACAP has increased VEGF expression levels in rats after bilateral common carotid artery occlusion (Szabo et al., 2012). Although the results appear contradictory at first, at biological level the finding further demonstrates how profoundly protective PACAP is. In the extreme hypoxia at carotid artery occlusion the only survival strategy is more capillaries, that PACAP can also provide by an adaptive switch in its signaling bias. Nevertheless, the antiVEGF effects of PACAP are clearly beneficial in patients suffering from DR conditions (Gabriel, 2013).

\section{Upregulation of HIF1alpha}

HIFs are important transcriptional regulators under hypoxic circumstances targeting quite a few genes including VEGF (Hu et al., 2003). Under reduced oxygen conditions, these factors could modulate the cellular response to hypoxia (Loboda et al., 2010; Manalo et al., 2011). The HIF1 protein has two types of subunits (i.e., HIF1- $\alpha$ and HIF1- $\beta$ ) that show oxygen-dependent expression; while HIF1- $\beta$ constitutively expressed, HIF1- $\alpha$ expression is increased under reduced oxygen concentrations (Jiang et al., 1996). During hypoxia, HIF1$\alpha$ forms dimers with HIF1- $\beta$ and the dimer binds to the HRE. This complex is able to regulate transcription of genes, which contribute to angiogenesis. One of them is the VEGF gene (Pugh and Ratcliffe, 2003). It has been previously shown that PACAP is able to modulate expression of HIFs in streptozotocin (STZ) induced diabetic retinas. After 3 weeks, HIF-1 alpha and HIF-2 alpha levels increased in diabetic groups and significantly decreased as a result of PACAP treatment. Conversely, HIF-3 $\alpha$ was downregulated in diabetic 


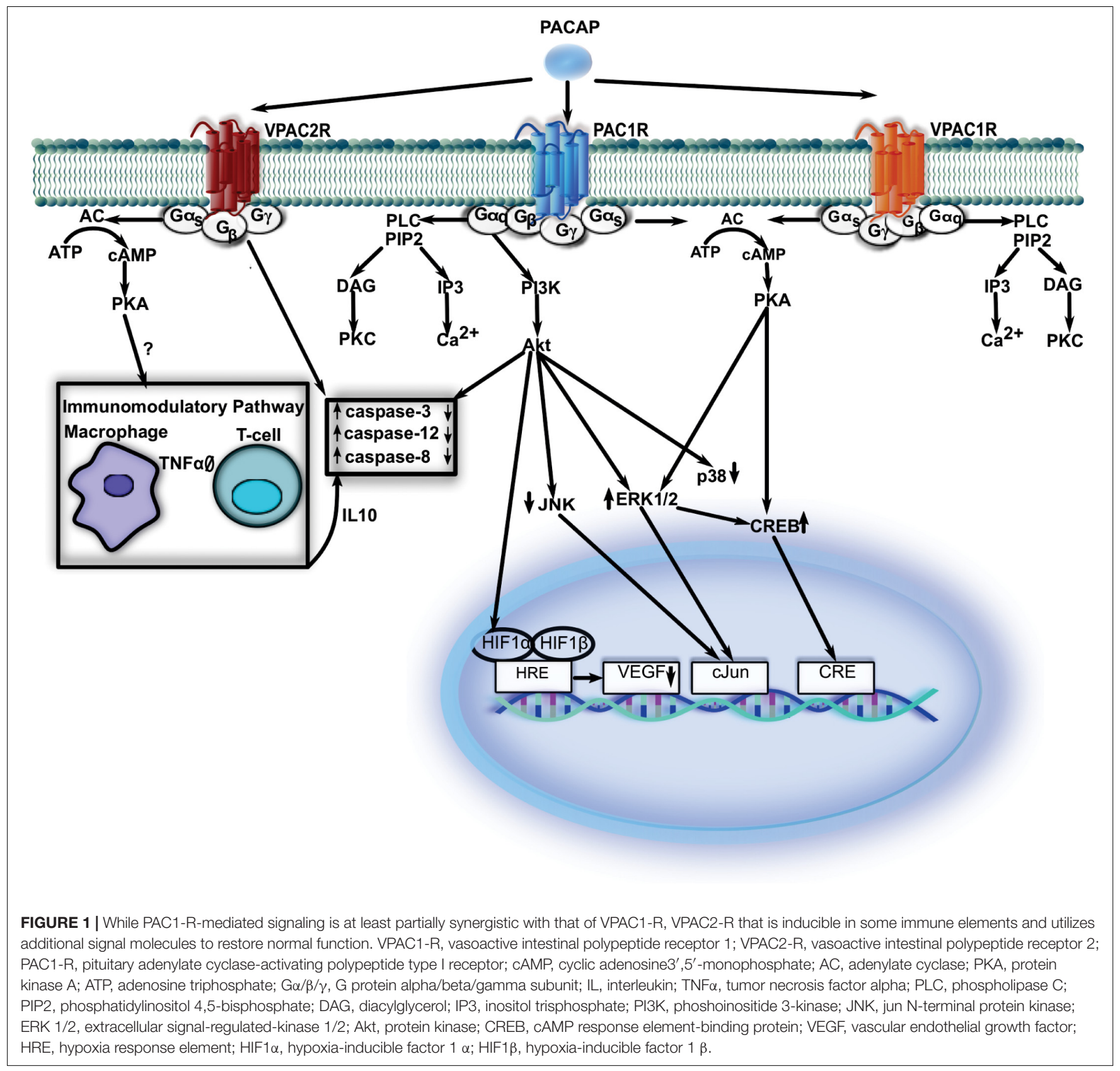

rats and enhanced after intraocular administration of PACAP (D'Amico et al., 2015). In normal conditions, HIF1 $\alpha$ level is reduced while HIF3 $\alpha$ level increases, unlike in hypoxia or hyperglycemia, where their expression patterns are reversed. Treatments with VIP or PACAP reduce HIF1 $\alpha$ levels and increase HIF3 $\alpha$ levels in ARPE-19 cells under hyperglycemic conditions (Maugeri et al., 2017).

\section{Downregulation of C-Jun and p38 \\ Kinases}

c-Jun N-terminal protein kinase (JNK) and p38 kinase are members of the MAPK superfamily and they regulate apoptotic signaling pathways in cells (Estus et al., 1994; Ham et al., 1995; Mesner et al., 1995). JNK can have both pro- and anti-apoptotic effects (Ham et al., 1995; Xia et al., 1995; Lenczowski et al., 1997). In experiments using sodium arsenite $\left(\mathrm{NaAsO}_{2}\right)$ to trigger neuronal apoptosis, both p38 kinase and JNK3 were upregulated and c-Jun phosphorylation was induced. The results showed that p38 kinase and JNK inhibitors attenuated apoptosis in cortical neurons and established the differences between JNK isoforms which differently contributed to the apoptotic processes (Namgung and Xia, 2000). It has also been described that intravitreal PACAP treatment decreased JNK, p38 activation and the activation of ERK1/2, AKT in hypoperfused 
rat retinas (Szabo et al., 2012). In MSG-induced retinal degeneration, PACAP treatment attenuated the activation of JNK and caspase 3 and increased the level of phosphoBad (Racz et al., 2006). On the contrary, the same group demonstrated that PACAP treatment decreased the expression and activation of pro-apoptotic p38 in diabetic rat retinas (Szabadfi et al., 2014).

\section{Synergism With Other Peptidergic Mechanisms}

The therapeutic potentials of different neuropeptides have been confirmed by numerous animal models of human diseases. These substances deserve prominent attention in the development of peptide-based therapeutic strategies of visionthreatening diseases.

The effectiveness of SST neuropeptide has been described in various pathological conditions of the retina. SST is an important neuromodulator and its immunoreactivity occurs mainly in the GABAergic amacrine cells in the retina (Feigenspan and Bormann, 1994; van Hagen et al., 2000). SST levels are downregulated at the early stage of DR (Carrasco et al., 2007). Topical administration of SST and its analogs have a preventive effect in retinal neurodegeneration in STZ-induced diabetes. It has been established that SST treatment inhibits extracellular glutamate accumulation, glial activation, ERG abnormalities and it modulates the proapoptotic/survival signaling pathways in experimental diabetes (Hernandez et al., 2013). Octreotide (OCTR) is a synthetic SST analog which, for example, in an ischemia/reperfusion injury study reduced cell loss, retinal thickness changes, ROS formation and inhibited NF-кB p65 activation. These findings demonstrated that OCTR application has a neuroprotective and antioxidant effect on ischemic injury in the retina (Wang et al., 2015). In another investigation, OCTR reduced hypoxia induced activation of STAT3 and HIF1 levels in retinal explants (Mei et al., 2012). OCTR and another SST analog (Woc4D) decreased neovascularization in the mouse model of oxygen-induced retinopathy (Higgins et al., 2002). A metabolomic analysis revealed the roles of PACAP, SP, and OCTR in ex vivo mouse models of retinal ischemia. These ex vivo results show a synergistic action of the above mentioned peptides. All treatments reduce VEGF overexpression, cell death and glutamate release and modulate pro-survival pathways by restoring IP3 signaling, cAMP levels and PIP2/PIP3 ratio in ischemia-induced retinal damages. It has also been demonstrated in ischemia related oxidative stress that PACAP and SP treatments help to cope with this condition and OCTR also contributes to the preventive effect in pathological processes (D'Alessandro et al., 2014).

Takuma et al. have investigated the effect of an enriched environment on memory impairments in PACAP deficientmice. This environment ameliorates the memory impairments in knockout mice after 4 weeks and the beneficial effects of it were also observed if mice were returned to a standard environment after 2 weeks. The results showed that the levels of BDNF, phospho-ERK, phospho-CaMKII and $N$-methyl D-aspartate receptor subtype $2 \mathrm{~B}(\mathrm{NR} 2 \mathrm{~B})$ in the hippocampus increased in an enriched environment and these factors are responsible for the ameliorating effect of the this environment on memory dysfunction. In PACAP $-/-$ mice, however, these increased expression levels disappeared after 2 weeks when they were returned to standard housing, so in the lack of PACAP the longlasting ameliorating effects of the enriched environment could not be verified (Takuma et al., 2014). An in vitro examination by Ogata and his colleagues have compared morphological effects of PACAP and BDNF on primary cultures of hippocampal neurons. Both PACAP and BDNF increased neurite length and numbers at a similar level, while PACAP increased the axon length only, but not the branching. Interestingly, the use of PACAP6-38 antagonist blocked both PACAP and BDNF-induced increases in axon length, suggesting that these two peptides may act through the same intracellular signal transduction machinery and that PACAP antagonists can interfere effectively with BDNF signaling (Ogata et al., 2015).

\section{Divergence in PACAP Receptor Signaling - How Immune Elements Are Recruited to Damaged Tissue Sites?}

It has been demonstrated that immune cells express functional PACAP receptors. However, PAC1-R has minor roles in the immune response whereas VPAC1-R and VPAC2-R signaling evoke diverging effects. The former is constitutively expressed on macrophages, while the latter is inducible and particularly strongly effected by LPS (Abad et al., 2016). While VPAC1-R is thought to act mainly as an inhibitor of the immune response, VPAC2-R is able to accelerate inflammatory processes by initiating the production of several cytokines, most prominently IL-6 and IL-10. Additionally, D'Amico et al. (2017) have provided evidence that both IL1ß and VEGF levels are modified in diabetic rat retinas after PACAP administration. In peripheral organs PACAP also activates T-lymphocytes. In PACAP KO mice, however, PACAP treatment failed to reduce neutrophil infiltration into organs indicating that other indirect downstream PACAP signaling is also essential in this system (Martinez et al., 2005). VPAC1 and VPAC2 receptors, but not PAC1$\mathrm{R}$ mRNA levels, were transiently induced in retinas 1 week following diabetes induction (Giunta et al., 2012). In the same diabetic condition, immune cells were attracted to the retina through the inner limiting membrane and resulted in strengthening of IL-6 but not tumor-necrosis factor (TNF) $\alpha$-immunoreactivity in retinal ganglion cells. The reason for this difference is currently unknown and research is needed to clarify the underlying signaling routes. It is even more interesting that $\mathrm{TNF} \alpha$ is dramatically increased in glaucoma and ischemia (Martinez et al., 2005). Therefore, it seems evident that not all of the microcircuitry-related disorders have identical immune cell recruitment pathways. This immune response may enhance the degeneration of the damaged cells. That, however, may be beneficial science when a protective signal like PACAP appears, it may be hasten the clearance of the dying elements, help to rearrange the neural connections and maintain the integrity of the remaining cells, to restore function as quickly as possible. 


\section{DISCUSSION}

Our review highlights the importance of PACAP and, some other neuropeptides in retinal degenerative diseases with metabolic origins. Neuropeptides with their wide range of signaling potential could modulate the pathological pathways of retinal diseases through converging signal pathways. The question arises why these potentials are neglected in drug development and subsequent clinical trials. One of the difficulties of using natural peptides as protective agents is their relatively short half-life (in some cases it can be shorter than $1 \mathrm{~min}$ ). The solution for this problem is to modify these peptides at their $\mathrm{N}$ and/or $\mathrm{C}$ termini in order to prevent degradation (acetylation, cyclization, $\mathrm{N}$ and/or C termini modification, PEGylation, D-amino acid substitution, etc.). In the case of PACAP, half-life can be longer than $4 \mathrm{~h}$ after some modifications (Mathur et al., 2016). Another potential problem using peptides as therapeutic agents is their limited passage through the blood brain barrier (Banks et al., 1993; Banks and Kastin, 1996). In the case of the retina there is no need for systemic administration since the peptides can injected into the vitreus body and must pass through the retinal inner limited membrane. Indeed it has been shown in the case of PACAP that it reaches the inner retinal layers after intravitreal injection (Werling et al., 2017).

At the same time, one of the mobilized downstream signals in the pathogenesis, VEGF is intensively targeted by different anti-VEGF therapies (Gabriel, 2013). While anti-VEGF therapies are expensive, synthesis and modification of peptides like PACAP are cost effective, so they may provide alternatives to the treatments available today in various retinal conditions, particularly in the case of DR. It would also be reasonable to consider the combination of modified neuropeptides, which can effectively counteract pathological retinal metabolic conditions. As discussed above, there are a number of candidates to be included in this mixture. In order to effectively protect every retinal cell type and layer we suggest trying the combination of

\section{REFERENCES}

Abad, C., Jayaram, B., Becquet, L., Wang, Y., O’Dorisio, M. S., Waschek, J. A., et al. (2016). VPAC1 receptor (Vipr1)-deficient mice exhibit ameliorated experimental autoimmune encephalomyelitis, with specific deficits in the effector stage. J. Neuroinflammation 13:169. doi: 10.1186/s12974-016-0626-3

Antonetti, D. A., Klein, R., and Gardner, T. W. (2012). Diabetic retinopathy. N. Engl. J. Med. 366, 1227-1239. doi: 10.1056/NEJMra1005073

Arimura, A., and Shioda, S. (1995). Pituitary adenylate cyclase activating polypeptide (PACAP) and its receptors: neuroendocrine and endocrine interaction. Front. Neuroendocrinol. 16:53-88. doi: 10.1006/frne.1995.1003

Atlasz, T., Szabadfi, K., Kiss, P., Racz, B., Gallyas, F., Tamas, A., et al. (2010). Pituitary adenylate cyclase activating polypeptide in the retina: focus on the retinoprotective effects. Ann. N. Y. Acad. Sci. 1200, 128-139. doi: 10.1111/j. 1749-6632.2010.05512.x

Atlasz, T., Szabadfi, K., Reglodi, D., Kiss, P., Tamas, A., Toth, G., et al. (2009). Effects of pituitary adenylate cyclase activating polypeptide and its fragments on retinal degeneration induced by neonatal monosodium glutamate treatment. Ann. N. Y. Acad. Sci. 1163, 348-352. doi: 10.1111/j.1749-6632.2008. 03650.x

Banks, W. A., and Kastin, A. J. (1996). Passage of peptides across the blood-brain barrier: pathophysiological perspectives. Life Sci. 59, 1923-1943. doi: 10.1016/ s0024-3205(96)00380-3 modified BDNF, CNTF, OCTR, and PACAP. These substances together satisfy the following criteria (i) under normal conditions their native form is present in the retina in low concentration; (ii) each retinal cell type has a receptor for at least one of the four peptides; (iii) the signal transduction pathways behind the retinal receptors of these substances do not ameliorate or cross each other's action; and (iv) none of them causes unwanted side effects even if they are given in higher concentrations. Considering that anti-VEGF drugs cost over 500 million pounds in Great Britain alone in 2015 (Hollingworth et al., 2017), alternatives are definitely needed, especially in low and medium income countries (Shanmugam, 2014). Clinical trials with the combinations of the above substances could be envisioned based on the results achieved on animal models in research laboratories.

\section{AUTHOR CONTRIBUTIONS}

All authors read and approved the final manuscript. RG wrote the manuscript and supervised the manuscript production. EP wrote the manuscript. VD gave expert advice and provided critical feedback.

\section{FUNDING}

Funding was provided by the Hungarian Scientific Research Fund (NKFIH) (Grant No. 119289) and EFOP-3.6.2-16-2017-00008.

\section{ACKNOWLEDGMENTS}

We would like to express our special thanks to Peter Geck for language editing. We also thank Alina Bolboaca for special assistance with editing the manuscript.

Banks, W. A., Kastin, A. J., Komaki, G., and Arimura, A. (1993). Passage of pituitary adenylate cyclase activating polypeptide1-27 and pituitary adenylate cyclaseactivating polypeptide1-38 across the blood-brain barrier. J. Pharmacol. Exp. Ther. 267, 690-696.

Basille, M., Vaudry, D., Coulouarn, Y., Jegou, S., Lihrmann, I., Fournier, A., et al. (2000). Comparative distribution of pituitary adenylate cyclase-activating polypeptide (PACAP) binding sites and PACAP receptor mRNAs in the rat brain during development. J. Comp. Neurol. 425, 495-509. doi: 10.1002/10969861(20001002)425:4<495::aid-cne3>3.3.co;2-1

Bourgault, S., Chatenet, D., Wurtz, O., Doan, N. D., Leprince, J., Vaudry, H., et al. (2011). Strategies to convert PACAP from a hypophysiotropic neurohormone into a neuroprotective drug. Curr. Pharm. Des. 17, 1002-1024. doi: 10.2174/ 138161211795589337

Bourgault, S., Vaudry, D., Dejda, A., Doan, N. D., Vaudry, H., and Fournier, A. (2009). Pituitary adenylate cyclase-activating polypeptide: focus on structureactivity relationships of a neuroprotective Peptide. Curr. Med. Chem. 16, 4462-4480. doi: 10.2174/092986709789712899

Carrasco, E., Hernandez, C., Miralles, A., Huguet, P., Farres, J., and Simo, R. (2007). Lower somatostatin expression is an early event in diabetic retinopathy and is associated with retinal neurodegeneration. Diabetes Care 30, 2902-2908. doi: $10.2337 / \mathrm{dc} 07-0332$

Casini, G. (2005). Neuropeptides and retinal development. Arch. Ital. Biol. 143, 191-198. 
Cervia, D., and Casini, G. (2013). The neuropeptide systems and their potential role in the treatment of mammalian retinal ischemia: a developing story. Curr. Neuropharmacol. 11, 95-101. doi: 10.2174/157015913804999423

Chalam, K. V., Brar, V. S., and Murthy, R. K. (2014). Human ciliary epithelium as a source of synthesis and secretion of vascular endothelial growth factor in neovascular glaucoma. JAMA Ophthalmol. 132, 1350-1354. doi: 10.1001/ jamaophthalmol.2014.2356

Cheung, N., Mitchell, P., and Wong, T. Y. (2010). Diabetic retinopathy. Lancet 376, 124-136. doi: 10.1016/S0140-6736(09)62124-3

Curcio, C. A., and Drucker, D. N. (1993). Retinal ganglion cells in Alzheimer's disease and aging. Ann. Neurol. 33, 248-257. doi: 10.1002/ana.410330305

D'Alessandro, A., Cervia, D., Catalani, E., Gevi, F., Zolla, L., and Casini, G. (2014). Protective effects of the neuropeptides PACAP, substance P and the somatostatin analogue octreotide in retinal ischemia: a metabolomic analysis. Mol. Biosyst. 10, 1290-1304. doi: 10.1039/c3mb70362b

D’Amico, A. G., Maugeri, G., Rasà, D. M., Bucolo, C., Saccone, S., Federico, C., et al. (2017). Modulation of IL-1 $\beta$ and VEGF expression in rat diabetic retinopathy after PACAP administration. Peptides 97, 64-69. doi: 10.1016/j.peptides

D’Amico, A. G., Maugeri, G., Reitano, R., Bucolo, C., Saccone, S., Drago, F., et al. (2015). PACAP Modulates expression of hypoxia-inducible factors in streptozotocin-induced diabetic rat retina. J. Mol. Neurosci. 57, 501-509. doi: 10.1007/s12031-015-0621-7

Danyadi, B., Szabadfi, K., Reglodi, D., Mihalik, A., Danyadi, T., Kovacs, Z., et al. (2014). PACAP application improves functional outcome of chronic retinal ischemic injury in rats-evidence from electroretinographic measurements. J. Mol. Neurosci. 54, 293-299. doi: 10.1007/s12031-014-0296-5

Dejda, A., Bourgault, S., Doan, N. D., Letourneau, M., Couvineau, A., Vaudry, H., et al. (2011). Identification by photoaffinity labeling of the extracellular $\mathrm{N}$-terminal domain of PAC1 receptor as the major binding site for PACAP. Biochimie 93, 669-677. doi: 10.1016/j.biochi.2010.12.010

Denes, V., Czotter, N., Lakk, M., Berta, G., and Gabriel, R. (2014). PAC1-expressing structures of neural retina alter their $\mathrm{PAC} 1$ isoform splicing during postnatal development. Cell Tissue Res. 355, 279-288. doi: 10.1007/s00441-013-1761-0

Elsas, T., Uddman, R., and Sundler, F. (1996). Pituitary adenylate cyclase-activating peptide-immunoreactive nerve fibers in the cat eye. Graefes Arch. Clin. Exp. Ophthalmol. 234, 573-580. doi: 10.1007/bf00448802

Esser, P., Heimann, K., and Wiedemann, P. (1993). Macrophages in proliferative vitreoretinopathy and proliferative diabetic retinopathy: differentiation of subpopulations. Br. J. Ophthalmol. 77, 731-733. doi: 10.1136/bjo.77.11.731

Estus, S., Zaks, W. J., Freeman, R. S., Gruda, M., Bravo, R., Johnson, E. M. Jr., et al. (1994). Altered gene expression in neurons during programmed cell death: identification of c-jun as necessary for neuronal apoptosis. J. Cell Biol. 127(6 Pt 1), 1717-1727. doi: 10.1083/jcb.127.6.1717

Feigenspan, A., and Bormann, J. (1994). Facilitation of GABAergic signaling in the retina by receptors stimulating adenylate cyclase. Proc. Natl. Acad. Sci. U.S.A. 91, 10893-10897. doi: 10.1073/pnas.91.23.10893

Ferrari, G., and Scagliotti, G. V. (1996). Serum and urinary vascular endothelial growth factor levels in non-small cell lung cancer patients. Eur. J. Cancer 32A, 2368-2369. doi: 10.1016/s0959-8049(96)00272-9

Filipsson, K., Sundler, F., Hannibal, J., and Ahren, B. (1998). PACAP and PACAP receptors in insulin producing tissues: localization and effects. Regul. Pept. 74, 167-175. doi: 10.1016/s0167-0115(98)00037-8

Flachsbarth, K., Kruszewski, K., Jung, G., Jankowiak, W., Riecken, K., Wagenfeld, L., et al. (2014). Neural stem cell-based intraocular administration of ciliary neurotrophic factor attenuates the loss of axotomized ganglion cells in adult mice. Invest. Ophthalmol. Vis. Sci. 55, 7029-7039. doi: 10.1167/iovs.14- 15266

Frank, R. N. (2004). Diabetic retinopathy. N. Engl. J. Med. 350, 48-58. doi: 10.1056/ NEJMra021678

Gabriel, R. (2013). Neuropeptides and diabetic retinopathy. Br. J. Clin. Pharmacol. 75, 1189-1201. doi: 10.1111/bcp.12003

Ganea, D., and Delgado, M. (2003). The neuropeptides VIP/PACAP and T cells: inhibitors or activators? Curr. Pharm. Des. 9, 997-1004. doi: 10.2174/ 1381612033455116

Gao, H., and Hollyfield, J. G. (1992). Aging of the human retina. Differential loss of neurons and retinal pigment epithelial cells. Invest. Ophthalmol. Vis. Sci. 33, $1-17$.

Gaucher, D., Chiappore, J. A., Paques, M., Simonutti, M., Boitard, C., Sahel, J. A., et al. (2007). Microglial changes occur without neural cell death in diabetic retinopathy. Vision Res. 47, 612-623. doi: 10.1016/j.visres.2006. 11.017

Giacco, F., and Brownlee, M. (2010). Oxidative stress and diabetic complications. Circ. Res. 107, 1058-1070. doi: 10.1161/CIRCRESAHA.110.223545

Giunta, S., Castorina, A., Bucolo, C., Magro, G., Drago, F., and D'Agata, V. (2012). Early changes in pituitary adenylate cyclase-activating peptide, vasoactive intestinal peptide and related receptors expression in retina of streptozotocininduced diabetic rats. Peptides 37, 32-39. doi: 10.1016/j.peptides.2012.06.004

Ham, J., Babij, C., Whitfield, J., Pfarr, C. M., Lallemand, D., Yaniv, M., et al. (1995). A c-Jun dominant negative mutant protects sympathetic neurons against programmed cell death. Neuron 14, 927-939. doi: 10.1016/0896-6273(95) 90331-3

Han, P., Liang, W., Baxter, L. C., Yin, J., Tang, Z., Beach, T. G., et al. (2014). Pituitary adenylate cyclase-activating polypeptide is reduced in Alzheimer disease. Neurology 82, 1724-1728. doi: 10.1212/WNL.0000000000000417

Hannibal, J. (2002). Pituitary adenylate cyclase-activating peptide in the rat central nervous system: an immunohistochemical and in situ hybridization study. J. Comp. Neurol. 453, 389-417. doi: 10.1002/cne.10418

Hernandez, C., Garcia-Ramirez, M., Corraliza, L., Fernandez-Carneado, J., Farrera-Sinfreu, J., Ponsati, B., et al. (2013). Topical administration of somatostatin prevents retinal neurodegeneration in experimental diabetes. Diabetes Metab. Res. Rev. 62, 2569-2578. doi: 10.2337/db12-0926

Higgins, R. D., Yan, Y., and Schrier, B. K. (2002). Somatostatin analogs inhibit neonatal retinal neovascularization. Exp. Eye Res. 74, 553-559. doi: 10.1006/ exer.2001.1147

Hollingworth, W., Jones, T., Reeves, B. C., and Peto, T. (2017). A longitudinal study to assess the frequency and cost of antivascular endothelial therapy, and inequalities in access, in England between 2005 and 2015. BMJ Open. 7:e018289. doi: 10.1136/bmjopen-2017-018289

Hu, C. J., Wang, L. Y., Chodosh, L. A., Keith, B., and Simon, M. C. (2003). Differential roles of hypoxia-inducible factor 1alpha (HIF-1alpha) and HIF2alpha in hypoxic gene regulation. Mol. Cell. Biol. 23, 9361-9374. doi: 10.1128/ mcb.23.24.9361-9374.2003

Izumi, S., Seki, T., Shioda, S., Zhou, C. J., Arimura, A., and Koide, R. (2000). Ultrastructural localization of PACAP immunoreactivity in the rat retina. Ann. N. Y. Acad. Sci. 921, 317-320. doi: 10.1111/j.1749-6632.2000.tb06985.x

Jiang, B. H., Semenza, G. L., Bauer, C., and Marti, H. H. (1996). Hypoxia-inducible factor 1 levels vary exponentially over a physiologically relevant range of $\mathrm{O} 2$ tension. Am. J. Physiol. 271(4 Pt 1), C1172-C1180. doi: 10.1152/ajpcell.1996. 271.4.C1172

Kaur, C., Foulds, W. S., and Ling, E. A. (2008). Hypoxia-ischemia and retinal ganglion cell damage. Clin. Ophthalmol. 2, 879-889. doi: 10.2147/opth.s3361

Kern, T. S. (2007). Contributions of inflammatory processes to the development of the early stages of diabetic retinopathy. Exp. Diabetes Res. 2007:95103. doi: $10.1155 / 2007 / 95103$

Kern, T. S., and Engerman, R. L. (1995). Galactose-induced retinal microangiopathy in rats. Invest. Ophthalmol. Vis. Sci. 36, 490-496.

Kim, M., Lee, C., Payne, R., Yue, B. Y., Chang, J. H., and Ying, H. (2015). Angiogenesis in glaucoma filtration surgery and neovascular glaucoma: a review. Surv. Ophthalmol. 60, 524-535. doi: 10.1016/j.survophthal.2015.04.003

Kiss, P., Atlasz, T., Szabadfi, K., Horvath, G., Griecs, M., Farkas, J., et al. (2011). Comparison between PACAP- and enriched environment-induced retinal protection in MSG-treated newborn rats. Neurosci. Lett. 487, 400-405. doi: 10.1016/j.neulet.2010.10.065

Kovacs, K., Vaczy, A., Fekete, K., Kovari, P., Atlasz, T., Reglodi, D., et al. (2019). PARP inhibitor protects against chronic hypoxia/reoxygenation-induced retinal injury by regulation of MAPKs, HIFlalpha, Nrf2, and NFkappaB. Invest. Ophthalmol. Vis. Sci. 60, 1478-1490. doi: 10.1167/iovs.18-25936

Kovacs-Valasek, A., Szabadfi, K., Denes, V., Szalontai, B., Tamas, A., Kiss, P., et al. (2017). Accelerated retinal aging in PACAP knock-out mice. Neuroscience 348, 1-10. doi: 10.1016/j.neuroscience.2017.02.003

Krady, J. K., Basu, A., Allen, C. M., Xu, Y., LaNoue, K. F., Gardner, T. W., et al. (2005). Minocycline reduces proinflammatory cytokine expression, microglial activation, and caspase- 3 activation in a rodent model of diabetic retinopathy. Diabetes Metab. Res. Rev. 54, 1559-1565. doi: 10.2337/diabetes.54.5.1559

Laburthe, M., Couvineau, A., and Tan, V. (2007). Class II G proteincoupled receptors for VIP and PACAP: structure, models of activation and pharmacology. Peptides 28, 1631-1639. doi: 10.1016/j.peptides.2007.04.026 
Lakk, M., Szabo, B., Volgyi, B., Gabriel, R., and Denes, V. (2012). Developmentrelated splicing regulates pituitary adenylate cyclase-activating polypeptide (PACAP) receptors in the retina. Invest. Ophthalmol. Vis. Sci. 53, 7825-7832. doi: 10.1167/iovs.12-10417

Lee, E. H., and Seo, S. R. (2014). Neuroprotective roles of pituitary adenylate cyclase-activating polypeptide in neurodegenerative diseases. BMB Rep. 47, 369-375. doi: 10.5483/bmbrep.2014.47.7.086

Lenczowski, J. M., Dominguez, L., Eder, A. M., King, L. B., Zacharchuk, C. M., and Ashwell, J. D. (1997). Lack of a role for Jun kinase and AP-1 in Fas-induced apoptosis. Mol. Cell. Biol. 17, 170-181. doi: 10.1128/mcb.17.1.170

Lipinski, D. M., Barnard, A. R., Singh, M. S., Martin, C., Lee, E. J., Davies, W. I. L., et al. (2015). CNTF gene therapy confers lifelong neuroprotection in a mouse model of human retinitis pigmentosa. Mol. Ther. 23, 1308-1319. doi: 10.1038/ mt.2015.68

Loboda, A., Jozkowicz, A., and Dulak, J. (2010). HIF-1 and HIF-2 transcription factors-similar but not identical. Mol. Cells 29, 435-442. doi: 10.1007/s10059010-0067-2

Lu, N., and DiCicco-Bloom, E. (1997). Pituitary adenylate cyclase-activating polypeptide is an autocrine inhibitor of mitosis in cultured cortical precursor cells. Proc. Natl. Acad. Sci. U.S.A. 94, 3357-3362. doi: 10.1073/pnas.94.7.3357

Lu, N., Zhou, R., and DiCicco-Bloom, E. (1998). Opposing mitogenic regulation by PACAP in sympathetic and cerebral cortical precursors correlates with differential expression of PACAP receptor (PAC1-R) isoforms. J. Neurosci. Res. 53, 651-662. doi: 10.1002/(sici)1097-4547(19980915)53:6<651::aid-jnr3>3.0. co;2- 4

Manalo, K. B., Choong, P. F., and Dass, C. R. (2011). Pigment epithelium-derived factor as an impending therapeutic agent against vascular epithelial growth factor-driven tumor-angiogenesis. Mol. Carcinog. 50, 67-72. doi: 10.1002/mc. 20711

Martinez, C., Juarranz, Y., Abad, C., Arranz, A., Miguel, B. G., Rosignoli, F., et al. (2005). Analysis of the role of the PAC1 receptor in neutrophil recruitment, acute-phase response, and nitric oxide production in septic shock. J. Leukoc. Biol. 77, 729-738. doi: 10.1189/jlb.0704432

Mathur, D., Prakash, S., Anand, P., Kaur, H., Agrawal, P., Mehta, A., et al. (2016). PEPlife: a repository of the half-life of peptides. Sci Rep. 6:36617. doi: 10.1038/ srep36617

Matsumoto, M., Nakamachi, T., Watanabe, J., Sugiyama, K., Ohtaki, H., Murai, N., et al. (2016). Pituitary adenylate cyclase-activating polypeptide (PACAP) is involved in adult mouse hippocampal neurogenesis after stroke. J. Mol. Neurosci. 59, 270-279. doi: 10.1007/s12031-016-0731-x

Maugeri, G., D'Amico, A. G., Bucolo, C., and D'Agata, V. (2019). Protective effect of PACAP-38 on retinal pigmented epithelium in an in vitro and in vivo model of diabetic retinopathy through EGFR-dependent mechanism. Peptides 119:170108. doi: 10.1016/j.peptides

Maugeri, G., D’Amico, A. G., Saccone, S., Federico, C., Cavallaro, S., and D’Agata, V. (2017). PACAP and VIP inhibit HIF-1alpha-mediated VEGF expression in a model of diabetic macular edema. J. Cell. Physiol. 232, 1209-1215. doi: $10.1002 /$ jcp. 25616

Mei, S., Cammalleri, M., Azara, D., Casini, G., Bagnoli, P., and Dal Monte, M. (2012). Mechanisms underlying somatostatin receptor 2 down-regulation of vascular endothelial growth factor expression in response to hypoxia in mouse retinal explants. J. Pathol. 226, 519-533. doi: 10.1002/path.3006

Mesner, P. W., Epting, C. L., Hegarty, J. L., and Green, S. H. (1995). A timetable of events during programmed cell death induced by trophic factor withdrawal from neuronal PC12 cells. J. Neurosci. 15, 7357-7366. doi: 10.1523/jneurosci. 15-11-07357.1995

Mester, L., Szabo, A., Atlasz, T., Szabadfi, K., Reglodi, D., Kiss, P., et al. (2009). Protection against chronic hypoperfusion-induced retinal neurodegeneration by PARP inhibition via activation of PI-3-kinase Akt pathway and suppression of JNK and p38 MAP kinases. Neurotox. Res. 16, 68-76. doi: 10.1007/s12640009-9049-6

Miyata, A., Arimura, A., Dahl, R. R., Minamino, N., Uehara, A., Jiang, L., et al. (1989). Isolation of a novel 38 residue-hypothalamic polypeptide which stimulates adenylate cyclase in pituitary cells. Biochem. Biophys. Res. Commun. 164, 567-574. doi: 10.1016/0006-291x(89)91757-9

Namgung, U., and Xia, Z. (2000). Arsenite-induced apoptosis in cortical neurons is mediated by c-Jun $\mathrm{N}$-terminal protein kinase 3 and p38 mitogen-activated protein kinase. J. Neurosci. 20, 6442-6451. doi: 10.1523/jneurosci.20-17-06442. 2000

Njaine, B., Martins, R. A., Santiago, M. F., Linden, R., and Silveira, M. S. (2010). Pituitary adenylyl cyclase-activating polypeptide controls the proliferation of retinal progenitor cells through downregulation of cyclin D1. Eur. J. Neurosci. 32, 311-321. doi: 10.1111/j.1460-9568.2010.07286.x

Nyisztor, Z., Denes, V., Kovacs-Valasek, A., Hideg, O., Berta, G., and Gabriel, R. (2018). Pituitary adenylate cyclase activating polypeptide (PACAP1-38) exerts both pro and anti-apoptotic effects on postnatal retinal development in rat. Neuroscience 385, 59-66. doi: 10.1016/j.neuroscience.2018.06.008

Ogata, K., Shintani, N., Hayata-Takano, A., Kamo, T., Higashi, S., Seiriki, K., et al. (2015). PACAP enhances axon outgrowth in cultured hippocampal neurons to a comparable extent as BDNF. PLoS One 10:e0120526. doi: 10.1371/journal.pone. 0120526

Pease, M. E., Zack, D. J., Berlinicke, C., Bloom, K., Cone, F., Wang, Y., et al. (2009). Effect of CNTF on retinal ganglion cell survival in experimental glaucoma. Invest. Ophthalmol. Vis. Sci. 50, 2194-2200. doi: 10.1167/iovs.08-3013

Pisegna, J. R., and Wank, S. A. (1996). Cloning and characterization of the signal transduction of four splice variants of the human pituitary adenylate cyclase activating polypeptide receptor. Evidence for dual coupling to adenylate cyclase and phospholipase C. J. Biol. Chem. 271, 17267-17274. doi: 10.1074/jbc.271.29. 17267

Pugh, C. W., and Ratcliffe, P. J. (2003). Regulation of angiogenesis by hypoxia: role of the HIF system. Nat. Med. 9, 677-684. doi: 10.1038/nm060 3-677

Racz, B., Gallyas, F. Jr., Kiss, P., Tamas, A., Lubics, A., Lengvari, I., et al. (2007). Effects of pituitary adenylate cyclase activating polypeptide (PACAP) on the PKA-Bad-14-3-3 signaling pathway in glutamate-induced retinal injury in neonatal rats. Neurotox. Res. 12, 95-104. doi: 10.1007/bf03033918

Racz, B., Gallyas, F. Jr., Kiss, P., Toth, G., Hegyi, O., Gasz, B., et al. (2006). The neuroprotective effects of PACAP in monosodium glutamate-induced retinal lesion involve inhibition of proapoptotic signaling pathways. Regul. Pept. 137, 20-26. doi: 10.1016/j.regpep.2006.02.009

Rahimi, N. (2006). Vascular endothelial growth factor receptors: molecular mechanisms of activation and therapeutic potentials. Exp. Eye Res. 83, 10051016. doi: 10.1016/j.exer.2006.03.019

Ramirez, J. M., Ramirez, A. I., Salazar, J. J., de Hoz, R., and Trivino, A. (2001). Changes of astrocytes in retinal ageing and age-related macular degeneration. Exp. Eye Res. 73, 601-615. doi: 10.1006/exer.2001.1061

Rayner, B. S., Duong, T. T., Myers, S. J., and Witting, P. K. (2006). Protective effect of a synthetic anti-oxidant on neuronal cell apoptosis resulting from experimental hypoxia re-oxygenation injury. J. Neurochem. 97, 211-221. doi: 10.1111/j.1471-4159.2006.03726.x

Reglodi, D., Atlasz, T., Szabo, E., Jungling, A., Tamas, A., Juhasz, T., et al. (2018). PACAP deficiency as a model of aging. Geroscience 40, 437-452. doi: 10.1007/ s11357-018-0045-8

Schratzberger, P., Geiseler, A., Dunzendorfer, S., Reinisch, N., Kahler, C. M., and Wiedermann, C. J. (1998). Similar involvement of VIP receptor type I and type II in lymphocyte chemotaxis. J. Neuroimmunol. 87, 73-81. doi: 10.1016/s01655728(98)00043-5

Seki, T., Shioda, S., Izumi, S., Arimura, A., and Koide, R. (2000). Electron microscopic observation of pituitary adenylate cyclase-activating polypeptide (PACAP)-containing neurons in the rat retina. Peptides 21, 109-113. doi: 10.1016/s0196-9781(99)00180-1

Seki, T., Shioda, S., Ogino, D., Nakai, Y., Arimura, A., and Koide, R. (1997). Distribution and ultrastructural localization of a receptor for pituitary adenylate cyclase activating polypeptide and its mRNA in the rat retina. Neurosci. Lett. 238, 127-130. doi: 10.1016/s0304-3940(97)00869-0

Shanmugam, P. M. (2014). Changing paradigms of anti-VEGF in the Indian scenario. Indian J. Ophthalmol. 62, 88-92. doi: 10.4103/0301-4738.126189

Silveira, M. S., Costa, M. R., Bozza, M., and Linden, R. (2002). Pituitary adenylyl cyclase-activating polypeptide prevents induced cell death in retinal tissue through activation of cyclic AMP-dependent protein kinase. J. Biol. Chem. 277, 16075-16080. doi: 10.1074/jbc.M110106200

Skeie, J. M., and Mullins, R. F. (2009). Macrophages in neovascular age-related macular degeneration: friends or foes? Eye 23, 747-755. doi: 10.1038/eye. 2008.206 
Spengler, D., Waeber, C., Pantaloni, C., Holsboer, F., Bockaert, J., Seeburg, P. H., et al. (1993). Differential signal transduction by five splice variants of the PACAP receptor. Nature 365, 170-175. doi: 10.1038/365170a0

Strand, F. L. (2003). Neuropeptides: general characteristics and neuropharmaceutical potential in treating CNS disorders. Prog. Drug Res. 61, 1-37. doi: 10.1007/978-3-0348-8049-7_1

Szabadfi, K., Atlasz, T., Kiss, P., Reglodi, D., Szabo, A., Kovacs, K., et al. (2012). Protective effects of the neuropeptide PACAP in diabetic retinopathy. Cell Tissue Res. 348, 37-46. doi: 10.1007/s00441-012-1349-0

Szabadfi, K., Reglodi, D., Szabo, A., Szalontai, B., Valasek, A., Setalo, G., et al. (2016). Pituitary adenylate cyclase activating polypeptide, a potential therapeutic agent for diabetic retinopathy in rats: focus on the vertical information processing pathway. Neurotox. Res. 29, 432-446. doi: 10.1007/ s12640-015-9593-1

Szabadfi, K., Szabo, A., Kiss, P., Reglodi, D., Setalo, G. Jr., Kovacs, K., et al. (2014). PACAP promotes neuron survival in early experimental diabetic retinopathy. Neurochem. Int. 64, 84-91. doi: 10.1016/j.neuint.2013.11.005

Szabo, A., Danyadi, B., Bognar, E., Szabadfi, K., Fabian, E., Kiss, P., et al. (2012). Effect of PACAP on MAP kinases, Akt and cytokine expressions in rat retinal hypoperfusion. Neurosci. Lett. 523, 93-98. doi: 10.1016/j.neulet.2012.06.044

Takuma, K., Maeda, Y., Ago, Y., Ishihama, T., Takemoto, K., Nakagawa, A., et al. (2014). An enriched environment ameliorates memory impairments in PACAPdeficient mice. Behav. Brain Res. 272, 269-278. doi: 10.1016/j.bbr.2014.07.005

Tamas, A., Gabriel, R., Racz, B., Denes, V., Kiss, P., Lubics, A., et al. (2004). Effects of pituitary adenylate cyclase activating polypeptide in retinal degeneration induced by monosodium-glutamate. Neurosci. Lett. 372, 110-113. doi: 10.1016/ j.neulet.2004.09.021

Tao, W., Wen, R., Goddard, M. B., Sherman, S. D., O’Rourke, P. J., Stabila, P. F., et al. (2002). Encapsulated cell-based delivery of CNTF reduces photoreceptor degeneration in animal models of retinitis pigmentosa. Invest. Ophthalmol. Vis. Sci. 43, 3292-3298.

Vaczy, A., Kovari, P., Kovacs, K., Farkas, K., Szabo, E., Kvarik, T., et al. (2018). Protective role of endogenous PACAP in inflammation-induced retinal degeneration. Curr. Pharm. Des. 24, 3534-3542. doi: 10.2174/1381612824 666180924141407

van Hagen, P. M., Baarsma, G. S., Mooy, C. M., Ercoskan, E. M., ter Averst, E., Hofland, L. J., et al. (2000). Somatostatin and somatostatin receptors in retinal diseases. Eur. J. Endocrinol. 143(Suppl. 1), S43-S51.

Vaudry, D., Falluel-Morel, A., Bourgault, S., Basille, M., Burel, D., Wurtz, O., et al. (2009). Pituitary adenylate cyclase-activating polypeptide and its receptors: 20 years after the discovery. Pharmacol. Rev. 61, 283-357. doi: 10.1124/pr.109. 001370

Vaudry, D., Gonzalez, B. J., Basille, M., Yon, L., Fournier, A., and Vaudry, H. (2000). Pituitary adenylate cyclase-activating polypeptide and its receptors: from structure to functions. Pharmacol. Rev. 52, 269-324.

Wang, G., Pan, J., Tan, Y. Y., Sun, X. K., Zhang, Y. F., Zhou, H. Y., et al. (2008). Neuroprotective effects of PACAP27 in mice model of Parkinson's disease involved in the modulation of K(ATP) subunits and D2 receptors in the striatum. Neuropeptides 42, 267-276. doi: 10.1016/j.npep.2008. 03.002

Wang, J., Sun, Z., Shen, J., Wu, D., Liu, F., Yang, R., et al. (2015). Octreotide protects the mouse retina against ischemic reperfusion injury through regulation of antioxidation and activation of NF-kappaB. Oxid. Med. Cell. Longev. 2015:970156. doi: 10.1155/2015/970156

Wang, Z., Han, X., Cui, M., Fang, K., Lu, Z., and Dong, Q. (2014). Tissue kallikrein protects rat hippocampal CA1 neurons against cerebral ischemia/reperfusioninduced injury through the B2R-Raf-MEK1/2-ERK1/2 pathway. J. Neurosci. Res. 92, 651-657. doi: 10.1002/jnr.23325

Wang, Z. Y., Alm, P., and Hakanson, R. (1995). Distribution and effects of pituitary adenylate cyclase-activating peptide in the rabbit eye. Neuroscience 69, 297-308. doi: 10.1016/0306-4522(95)00258-k

Wen, R., Tao, W., Li, Y., and Sieving, P. A. (2012). CNTF and retina. Prog. Retin. Eye Res. 31, 136-151. doi: 10.1016/j.preteyeres.2011.11.005

Werling, D., Banks, W. A., Salameh, T. S., Kvarik, T., Kovacs, L. A., Vaczy, A., et al. (2017). ). Passage through the ocular barriers and beneficial effects in retinal ischemia of topical application of PACAP1-38 in rodents. Int. J. Mol. Sci. 18:E675. doi: 10.3390/ijms18030675

Werling, D., Reglodi, D., Kiss, P., Toth, G., Szabadfi, K., Tamas, A., et al. (2014). Investigation of PACAP fragments and related peptides in chronic retinal hypoperfusion. J. Ophthalmol. 2014:563812. doi: 10.1155/2014/563812

Xia, Z., Dickens, M., Raingeaud, J., Davis, R. J., and Greenberg, M. E. (1995). Opposing effects of ERK and JNK-p38 MAP kinases on apoptosis. Science 270, 1326-1331. doi: 10.1126/science.270.5240.1326

Yancopoulos, G. D., Davis, S., Gale, N. W., Rudge, J. S., Wiegand, S. J., and Holash, J. (2000). Vascular-specific growth factors and blood vessel formation. Nature 407, 242-248. doi: 10.1038/35025215

Yau, J. W., Rogers, S. L., Kawasaki, R., Lamoureux, E. L., Kowalski, J. W., Bek, T., et al. (2012). Global prevalence and major risk factors of diabetic retinopathy. Diabetes Care 35, 556-564. doi: 10.2337/dc11-1909

Zeng, H. Y., Green, W. R., and Tso, M. O. (2008). Microglial activation in human diabetic retinopathy. Arch. Ophthalmol. 126, 227-232. doi: 10.1001/ archophthalmol.2007.65

Zeng, X. X., Ng, Y. K., and Ling, E. A. (2000). Neuronal and microglial response in the retina of streptozotocin-induced diabetic rats. Vis. Neurosci. 17, 463-471. doi: $10.1017 / \mathrm{s} 0952523800173122$

Conflict of Interest: The authors declare that the research was conducted in the absence of any commercial or financial relationships that could be construed as a potential conflict of interest.

Copyright (c) 2019 Gábriel, Pöstyéni and Dénes. This is an open-access article distributed under the terms of the Creative Commons Attribution License (CC BY). The use, distribution or reproduction in other forums is permitted, provided the original author(s) and the copyright owner(s) are credited and that the original publication in this journal is cited, in accordance with accepted academic practice. No use, distribution or reproduction is permitted which does not comply with these terms. 